FICTION BOOK REVIEW

\section{Unexpected Lessons in Love}

Bernardine Bishop. London, UK: John Murray, 2013. ISBN-13: 978-1-848-54784-1. Price:

f7.99. Pages: 384 (paperback)

Bernardine Bishop's new novel follows the journey of Celia diagnosed with colonic cancer, through the emotional rollercoaster of that condition.

The cancer, however, is only a backdrop to the other emotional rollercoasters provided by her son's unexpected 'fatherhood', the abandonment of the baby by its mentally ill mother, a friend's parallel struggles with cancer, an abduction, an adoption, a marriage, a birth and a death, through to the final, though equivocally happy, ending.

These various plotlines cast light not only on the nature of life, illness and mortality, but crucially also on the nature of parenthood. Without revealing the twists and turns of the story, there are in this novel many fathers and mothers who are not what they seem, many who selfishly walk away from parental responsibility, and many who take on that responsibility in a way so utterly unselfish that it borders on the self-sacrificial.

Which leads us neatly on to the aspects of the book that left this reader, at least, a little dismayed. So many of the characters seem to act without moral imperative where children are concerned. Offspring are loved but they are also overindulged, abandoned, annexed, illegally adopted and roundly rejected. And so many of the plotlines seem to support these actions without regard to everyday reality. For example, would Social Services really agree to accept a child for adoption simply because the mother had had a disturbed night?

Where Bishop's treatment of her subject matter does ring true, however and where it may give the reader crucial and useful insights - is in its descriptions of living with cancer. We learn from the cover blurb that Bernardine Bishop herself has suffered from the disease, and that experience has certainly informed her writing. Both Celia and friend Helen's emotions - as well as the emotions of those family and friends who surround them - absolutely reflect the impact of the disease: the uncertainty, the hope, the despair and the daily struggle for resilience.

In short, do not read this book if what you seek are good role models of ethical and wise parenting, though its themes may make you think more deeply about the responsibilities of family life. But if you - professionally or personally want to understand the emotional journey that cancer sufferers take, order your copy from Amazon now.

\section{Reviewed by Susan Quilliam}

Freelance Writer, Broadcaster and Agony Aunt, Cambridge, UK; susan@susanquilliam.com

J Fam Plann Reprod Health Care 2013;39:275. doi:10.1136/jprhc-2013-100753 